\title{
Watching Over the Rights of Women
}

\author{
Helen Jones* and Kas Wachala** \\ * Department of Sociology, Manchester Metropolitan University, UK \\ E-mail: h.jones@mmu.ac.uk \\ ** Department of Law and Criminology, Edge Hill College of Higher Education, Ormskirk, UK
}

This article examines the implementation of the Convention on the Elimination of All Forms of Discrimination Against Women (CEDAW) to critically consider its effectiveness as a bill of rights for women. After having discussed the need for such a convention for women it examines the vital role that non-governmental organisations (NGOs) play in the implementation of the Convention. As of March 2005, 180 countries - 90 per cent of the members of the United Nations - were party to this Convention. However, the document is one of the most highly reserved international human rights instruments and although many nations have ratified the Convention they have done so conditionally. Despite these reservations, women's NGOs have used CEDAW as a powerful tool to effect change. Yet, whilst CEDAW has been heralded as a significant step in the development of international human rights, women across the globe still suffer abuse because they are women. There is a need therefore to suggest ways forward in order to ensure the improvement of human rights for women.

\section{Introduction}

The Convention on the Elimination of All Forms of Discrimination Against Women (CEDAW) is an international convention that was adopted by the United Nations General Assembly in 1979 and came into force in 1981. It states that:

discrimination against women violates the principles of equality of rights and respect for human dignity, is an obstacle to the participation of women, on equal terms with men, in the political, social, economic and cultural life of their countries, hampers the growth of the prosperity of society and the family and makes more difficult the full development of the potentialities of women in the service of their countries and of humanity. ${ }^{1}$

The Convention, also known as 'The Women's Convention', was the first document that comprehensively addressed women's rights within civil, political, cultural, economic and social spheres. Stewart (2004: 6) succinctly documents the historical development of the Convention through an appraisal of its vision and aspirations claiming that it marks 'a new era in human rights instruments'. The creation of the Convention can, therefore, be seen as the first step in developing a human rights framework for women. This is articulated in the definition of discrimination set out in Article 1 that highlights any:

distinction, exclusion or restriction made on the basis of sex which has the effect or purpose of impairing or nullifying the recognition, enjoyment or exercise by women, irrespective of marital 
status, on the basis of equality between men and women, of human rights or fundamental freedoms in the political, economic, social, cultural, civil, or any other field.

It is important to note that the Convention imposes obligations on states in respect of this discrimination by private parties and not just by the state or its agents. Article 18 obliges states to submit regular reports on the 'Legislative, judicial, administrative or other measures which they have adopted to give effect to the provisions of the Convention... and on progress made'. Thus, according to Article 18, it is mandatory that states report on the steps that they have taken to eliminate discrimination against women.

States report every four years ${ }^{2}$ and in January 1999, the CEDAW Committee formally invited non-governmental organisations (NGOs) to participate in this process. Although NGOs are not permitted to speak at meetings where the CEDAW Committee is considering the state report, NGOs are permitted to produce a shadow report (Benedek, Kisaakye and Aberleitner 2002: 138). The impact of NGOs on this process should not be underestimated. NGO shadow reports do play an important role as they provide an alternative view of the situation and can often contradict the official state report. Members of the CEDAW Committee have had favourable responses to these shadow reports and indeed have used them to interrogate the state in question.

As of March 2005, 180 countries - 90 per cent of the members of the United Nations are party to the Convention. ${ }^{3}$ The most recent states to ratify the Convention were Afghanistan $^{4}$ (5 March 2003), Sao Tome and Principe (3 June 2003) and San Marino (10 December 2003). Monaco acceded in March 2005. The USA (and a small number of other countries including Iran and Palestine) have ratified the Convention. Amnesty International has criticised the USA for being the only industrialised democracy that has failed to do so:

Women around the world need the United States to speak loudly and clearly in support of CEDAW so that it becomes a stronger instrument in support of their struggles. Without US ratification, some other governments feel free to ignore CEDAW's mandate and their obligations under it. (Amnesty International, 2001: 7)

\section{Why human rights for women?}

CEDAW raises certain fundamental questions. Perhaps the most important of these is why do women need a separate convention when there are other conventions and treaties, which are universal in application? Does the existence of these conventions and treaties mean that the idea or notion of a separate women's bill of rights is in fact redundant? Coomaraswamy (1994) and others (Bunch, 1995; Tang and Cheung, 2000; Nash, 2002) have suggested that these universal treaties are flawed as they do not in fact address the problems, discrimination and abuse that women face in their day-to-day lives. A vital question to address therefore is: Why do these universally applicable conventions not adequately deal with women's human rights?

Modern human rights are firmly rooted in western liberalism and, as the public/private 'dichotomy is central to liberalism' (Charlesworth, 1994: 68), human rights instruments have traditionally concentrated on political and civil rights as opposed to economic and social rights. This is problematic for women as it is the case that many women across the globe still operate in the private sphere. The impact of this on the human rights of women 
has been enormous. The transportation of the public/private divide into the politics and the law of human rights has to be challenged because otherwise women and their needs will remain invisible.

\section{Is CEDAW effective?}

Although CEDAW provides an international mechanism to address violence against women in the private domain by non-state actors, it is necessary to consider how effective it is. There are three main issues to discuss here - reservations, petition mechanisms and delays.

\section{Reservations}

Although many nations have ratified the Convention they have done so conditionally. It may be hoped that, by allowing reservations, states will move progressively towards the ethos of CEDAW, but it is also just as likely that such reservations threaten such a goal. Many of the substantive reservations are wide-ranging and they affect the integrity of the Convention. For example, Article 2(f) states that all state parties should: 'take all appropriate measures including legislation, to modify or abolish existing laws, regulations, customs and practices which constitute discrimination against women'.

This has attracted a large number of reservations as it is deemed to conflict with the internal law of some state parties. Weiss (2003: 584) points out that many of the 23 Muslim majority states that are party to the Convention have voiced concern that specific sections of CEDAW might be 'contradictory to Islamic tenets'. Bangladesh, for example, has stated that it considers itself not to be bound by CEDAW articles that conflict with Sharia law based on the Holy Qu'ran (Mayer, 1998). The Independent Centre for Strategic Studies and Analysis (ICSSA) is critical of UN conventions and treaties, which:

have been used to browbeat nations with moral objections into submission. In the past year, [CEDAW] representatives.... told the government of Libya to reinterpret the Koran within the framework of UN guidelines. Is the committee justified to go to this extent? ${ }^{5}$

ICSSA go on to ask - 'Are we ready to surrender our religious beliefs and national sovereignty?' Throughout the Muslim world, women's NGOs have worked to increase state compliance with the Convention. Dairiam (2003) has pointed out that Indonesia has no reservations, despite it being the country with the world's largest Muslim population. However, the CEDAW Committee has found that in reality women in Indonesia remain unequal to men 'because of a combination of traditional and cultural practices and certain laws that are contrary to the spirit, if not the letter, of the principle of equality'. ${ }^{6}$ So, even when countries do not make reservations they can still choose to ignore the Convention and this strikes at the very heart of the Convention and threatens its effectiveness (Afsharipour, 1999; Ali and Rehman, 2003). Ilumoka claims that this 'systematic violation appears to be more the rule than the exception in most parts of the world' (1994: 308). Dairiam, argues that a 'serious impediment to equality for women is the prevalence of culture and tradition, which impact on societal values and make existing legal frameworks ineffective' (2003: 134). A recent example is that of elections in Saudi Arabia. ${ }^{7}$ Women were excluded from voting or standing for election despite this being 
contrary to Saudi Arabia's election law, which does not ban women from taking part. This exclusion undermines ratification of CEDAW and, yet, the ratification by Saudi Arabia in October 2000 was done without reservation to Article 7 on political participation.

\section{Petition mechanisms}

Women are further marginalised in the international community because CEDAW, along with most human rights documents, was constructed without an individual petition mechanism. This can be contrasted with the European approach to the enforceability of human rights, which is unique in this respect. Under the European Convention of Human Rights and Fundamental Freedoms an enforcement mechanism exists to allow individuals to petition the European Court of Human Rights. This acts as an effective mechanism to persuade state parties to adhere to the rights laid down. An illustrative example is where the European Court of Human Rights issued a judgment in the individual petition of M.C. v. Bulgaria in $2003 .^{8}$ It held the government of Bulgaria in violation of the European Convention for the Protection of Human Rights and Fundamental Freedoms for the failure of Bulgarian prosecutors to investigate sufficiently a rape allegation that the applicant had made when she was 14 years old in 1995. Interpreting Articles 3 and 8 of the Convention it was stated that the 'Court considers that States have a positive obligation to enact criminal law provisions effectively punishing rape and to apply them in practice through effective investigation and prosecution'. In the case of M.C. the Court found 'that the effectiveness of the investigation of the applicant's case fell short of the requirements'. The Court awarded the applicant damages, costs and expenses totaling 12,110 euros.

Without such an individual petition, how did the international community envisage that state parties would adhere to the rights laid down for women in CEDAW? Article 18 introduces a reporting mechanism to be adopted by state parties but many states fail to adhere to the reporting obligation. An attempt to counter this has been the adoption of the Optional Protocol. The UN adopted the Optional Protocol to CEDAW in October 1999, as a consequence of the 1993 Vienna Convention on Human Rights and the 1995 Fourth World Conference on Women, and it entered into force on the 22 December 2000 for those countries which ratified it. It is a significant addition to CEDAW on two levels.

Firstly it introduces a complaints procedure to CEDAW. Under the Optional Protocol individuals or groups of individuals are given locus standi. The possibility for a group action is important given the structural nature of inequality experienced by women. Communications may be submitted to the CEDAW Committee by or on behalf of individuals or groups of individuals who claim to have had their convention rights violated. However a communication can only be made to the CEDAW Committee once all national remedies have been exhausted (Article 4). Further if the complainant is having the matter considered under another international procedure, they are not able to use the CEDAW Optional Protocol.

Secondly, the Optional Protocol introduces an inquiry procedure. This is a mechanism whereby the CEDAW Committee can make comments and recommendations on 'grave or systematic' violations of CEDAW rights. There is a two-stage procedure involved in the inquiry process: a confidential stage and a public stage. At the confidential stage of the inquiry, the Committee receives reliable information about the alleged 'grave or systematic' violations. The state party is then invited to cooperate in the inquiry and to submit its own observations. One or more of the members of the committee then considers 
these submissions and finally the Committee makes its findings. The state party then has six months to consider the views and provide a written response, which should include the remedial steps that are to be taken. Once this has occurred the inquiry becomes public information.

Unlike CEDAW itself, the Optional Protocol does not have a reservation clause. It does however include an 'opt out' clause in the form of Article 10. This Article allows state parties, on ratification or accession, to 'opt out' of the inquiry procedure. As of 15 April 2005, there were 71 countries that had signed or ratified the Optional Protocol (these countries are otherwise known as OP-CEDAW parties). Another way of considering this is that of the 180 parties to the CEDAW Convention, 109 are not bound by the Optional Protocol. ${ }^{9}$

However, the Optional Protocol is important for a number of reasons. It helps to reaffirm already existing remedies under other international human rights instruments. ${ }^{10}$ It can also be seen as a development of international human rights law, improving the monitoring mechanisms. The Optional Protocol will thus allow the CEDAW Committee to develop legal principles on women's rights as they are interpreting the Convention. Perhaps, most importantly, it recognises that human rights need additional mechanisms in order to be protected and the Optional Protocol is the obvious next stage in that it attempts to give CEDAW legal teeth. As Mary Robinson, UN High Commissioner for Human Rights (1997-2002) notes:

In addition to providing an international remedy for the violations of women's rights, the Optional Protocol will act as an incentive for Governments to take a fresh look at the means of redress that are currently available to women at the domestic level. ${ }^{11}$

The United Kingdom has only recently ratified the Optional Protocol. On 17 December 2004 the UK, after a major review of obligations under UN Human Rights Instruments, decided to ratify the Optional Protocol. Thus women in the UK are no longer denied both the right of individual petition to the CEDAW Committee and the possibility of an inquiry into 'grave and systematic' violations of their rights.

\section{Delays}

There are serious delays in hearing the reports. Delays are exacerbated firstly by a backlog of overdue reports and secondly because the CEDAW Committee is only given a twoweek period in which they may meet. The Committee has taken the view that no more than ten reports may validly be considered during this period. Thus the build up of a backlog is inevitable and has the effect of rendering the only enforcement mechanism of CEDAW less and less effective.

The Committee is considerably behind in its work, which has meant long delays in the examination of reports. For example, in the case of United Kingdom, which ratified the Convention in 1985, its second report was examined in 1993 and its third report (submitted in 1995) was not looked at until 1999. By that time, the material it contained had been largely superseded by its 1999 report. Also, information supplied by some countries is so overwhelming for the Committee that it looks only at the parts that have given concern in the reports of other countries. $^{12}$ 
It is worthy to note at this juncture that every other human rights treaty and convention body is allocated a greater length of time for meetings: usually between three to nine weeks per year. For example the Torture Committee, founded under the Torture Convention, meets for four weeks a year: this is despite the fact that there are fewer ratifications for the Torture Convention to consider than there are for CEDAW. There is also a geographical anomaly in that other human rights bodies are based in Geneva, while CEDAW and the Commission on the Status of Women are based in Vienna. It may be argued therefore that 'gender-related issues are not receiving sufficient attention from other UN human rights bodies' (Tang and Cheung, 2000: 11). In the late 1990s an extension to the two-week period was granted in exceptional circumstances but the backlog still exists.

\section{Using CEDAW and the role of NGOs}

The role of NGOs in acting as unofficial ombudsmen has long been recognised as a tool for ensuring that nation states adhere to their commitments to international human rights instruments (Weissbrodt, 1977). CEDAW was not constructed out of the benevolence of state governments: it emerged from a developing feminist awareness across the globe and should be seen as part of the 'advances which women have made towards claiming their rights' (Tang and Cheung, 2000: 17). Despite the undoubted gains that have been made for women, it is vital that such victories do not slip away. The role of NGOs is crucial in holding the nation state to account and it would appear that many governments are sensitive to criticisms made by NGOs regarding state performance on the implementation of CEDAW. Women's NGOs have made effective use of this sensitivity. Although problems surrounding enforcement of CEDAW rights have been highlighted, it is important to explore the ways in which women and NGOs assert political and civil pressure on state parties to enforce CEDAW. One area in which CEDAW particularly holds utility for women is the area of male violence against women. It has been recognised that:

Violence against women seriously inhibits women's ability to enjoy inalienable rights and freedoms on a basis of equality with men. But, violence against women itself emerges from the phenomenon of discrimination against women, which makes them a target of violence. (Amnesty International, 2001: 18)

Thus CEDAW can ostensibly be used to combat both discrimination against women and violence against women. Originally the remit of CEDAW did not focus upon addressing violence against women. However, the CEDAW Committee is empowered to make recommendations on any issue affecting women to which it believes the state's parties should devote more attention. In 1989, the Committee discussed the issue of violence against women and in 1992 the Committee adopted General Recommendation 19. This requires all national reports to the Committee to include statistical data on:

- the incidence of violence against women;

- information on legislative and other measures taken to protect women against violence in their everyday lives; and

- information on the provision of services for victims.

These General Recommendations are crucial as they supplement and interpret the Convention and also provide the direction that state parties should be taking in addressing 
Convention rights. It should be noted that these recommendations are not binding on states. However, they are important as they are seen to be persuasive interpretations of CEDAW rights.

Across the globe, NGOs are working towards ensuring that CEDAW is implemented within their own nation states by using the Convention as an advocacy tool and, in so doing, are allowing women to gain conviction of the legitimacy of their rights.

In the UK, the shadow report from NGOs was prepared and facilitated by the Women's National Commission, with contributions from Womankind and the Women's Resource Centre (WRC) (Stewart, 2004). This process has co-ordinated the work of many women's groups. Interestingly, the WRC conducted research on their member groups and found that many did not have much prior knowledge of the CEDAW Convention and that, 'Only 27 percent of respondents have used CEDAW in advocacy, lobbying and day-to-day work' (Women's Resource Centre, 2002: 9). Further afield, however, there are many examples of NGOs using CEDAW for the attainment of women's rights (Stewart, 2004). The United Nations Development Fund for Women (UNIFEM) has worked extensively with NGOs in Asia/Africa/Pacific in preparing reports to the CEDAW Committee.

In the Africa region, UNIFEM's support led to CEDAW's adoption as a tool for the Constitutional and Legislative Review Commission in Rwanda. The successful and effective use of CEDAW in facilitating efforts to eradicate Female Genital Mutilation (FGM) in Senegal is being replicated by NGOs in Burkina Faso at the community level. In Malawi, government representatives participating in a UNIFEM-sponsored workshop on CEDAW committed to review national laws to bring them into compliance with the Convention. (emphasis in original) ${ }^{13}$

UNIFEM is not the only group actively working to promote the CEDAW Convention. In 1985 the International Women's Rights Action Watch (IWRAW) was formed at a conference in Nairobi, Kenya. The remit of this organisation is quite simply to promote recognition of CEDAW rights. IWRAW produces publications which act as guides to using CEDAW and provides training and technical assistance to individuals and groups on the implementation of CEDAW rights. In 1993, a sister organisation was formed in Malaysia called International Women's Rights Action Watch Asia Pacific. IWRAW Asia Pacific works to promote 'an effective flow of information on the CEDAW Convention between the local and the global levels ... [it] facilitates a process through which CEDAW is used as a tool for applying international human rights standards at the national level' ${ }^{14}$

Central Asia is also actively using CEDAW to advance women's rights. In Mongolia, there are 2,700 registered NGOs and 78 of these state their interest as 'women's rights' (Lawyers Center for Legal Reform Support, 2002: 6). However, only three take violence against women as a priority: the CEDAW Watch Centre, the National Centre Against Violence (NCAV) ${ }^{15}$ and the Mongolian Women Lawyers Association (MWLA) are all engaged in actively challenging the state. Mongolia's 3rd and 4th periodic reports to CEDAW were read together in 2001. The Committee noted that there were 'no remedies available to women to redress violations of their rights' and that the 'phenomenon of violence against women has not been adequately addressed in laws, policies and programs' (UNIFEM Trust Fund, 2002: 5). Women's NGOs used the CEDAW recommendations as leverage to draft a law against domestic violence. The NCAV and the MWLA conducted a series of events in support of the draft and lobbied 
government ministers and their spouses to gain support for the draft legislation. On 13 May 2004, the Parliament of Mongolia unanimously adopted the Domestic Violence Bill.

From the above examples, the role of NGOs can be seen to be of crucial importance in ensuring that nation states adhere to their commitment to women's rights. The proactive stance that women's NGOs have taken suggests that there now exists a 'parallel' international community: an international civil society that works outside or at the margins of official state activities. Young (1990) argues that the civic space is likely to become increasingly important especially in the enforcement of international law. Thus women, by working through NGOs and other bodies, are able to influence the development, interpretation and implementation of international law.

Although CEDAW itself can be seen to be a 'weak' Convention the role that NGOs play means CEDAW can become a more effective tool in the fight for anti-discriminatory practices against women. The participation of NGOs might shape CEDAW's future progress and effectiveness. Despite the fact that NGOs 'dance in the normative margins of international law' (Knop, 1993: 316), it is perhaps better to engage in the dance than to 'sit it out'.

\section{Conclusion}

CEDAW has been heralded as a significant step in the development of international human rights; it has been welcomed as a bill of rights for women and as a visionary Convention which will address gender specific abuses of rights. However, how can CEDAW be taken forward and moved closer to towards achieving its vision or should the human rights framework be abandoned by feminists?

One response is to reject the human rights model, including CEDAW and thus to 'opt out' of the international human rights legal system (Phillips, 1992). Thus, Tang and Cheung (2000: 7) criticise optimists who 'contend that once a country adopts it, beneficial effects are inevitable' and from this position it might be argued that the campaign for women's rights is misguided and in fact is detrimental to women. Such an argument would see Human Rights instruments such as CEDAW as acting as a smokescreen obscuring the real issue of power relations between men and women. The existence of CEDAW does, however, offer a formal mechanism through which the issue of violence against women can be highlighted on a national platform. It is not CEDAW that blocks access to equal rights but the lack of a sincere political will.

A more favoured response is to accept the deficiencies of CEDAW but to then work within the international legal system to ensure that women's rights become part of the legal culture of the international community: to turn the myth of women's rights into a reality (Charlesworth, 1994; Bunch, 1995; Nash, 2002). To understand the flaws of CEDAW is crucial, but if women are to ensure that the rights laid down in CEDAW are not merely men's rights masquerading as women's rights they must use the machinery of CEDAW creatively.

Our own analysis has shown that the involvement of NGOs can make a significant difference in the monitoring of state parties adherence to the Convention and can also act as a catalyst to change. In particular, the production of shadow reports by NGOs that challenge the government's response to CEDAW is crucial. 
Furthermore, nation states should incorporate CEDAW into national legislation and sign up to the Optional Protocol. Women need to make their governments accountable for the abuses that are suffered. This cannot be achieved by opting out of the system. It has been argued that setting international standards 'represents the first, crucial step towards gender justice' (Tang and Cheung, 2000: 8) but the next steps will only be achieved by using (and not merely accepting) the tools which CEDAW offers. Women must therefore utilise all the tools at their disposal and one of these tools is CEDAW.

\section{Notes}

1 Convention on the Elimination of All Forms of Discrimination against Women, Preamble.

2 For a list of Country Reports see http://www.un.org/womenwatch/daw/cedaw/reports.htm (accessed 12 May 2005).

3 Full details are available at http://www.un.org/womenwatch/daw/cedaw/states.htm (accessed 12 May 2005).

4 Amnesty International has recently called on the Afghan government to uphold its obligation to end the culture of violence through which women continue to be targeted and victimised. This was in response to the deaths of three Afghan women who had been involved in NGOs in Afghanistan. The women were raped and strangled on 1 May 2005. Al Index: 12 May 2005.

5 See the website - http://icssa.org/ICSS\%20-\%20themes_moral_Beijing_plus_five.htm (accessed 12 May 2005).

6 Concluding Observations by CEDAW Committee on Indonesia 1998: http://www1.umn.edu/ humanrts/cedaw/indonesia1998.html

7 For further information see the CNN news website: http://www.cnn.com/2005/WORLD/meast/ 04/23/saudi.elections.ap/ (accessed 12 May 2005).

8 Judgment accessible through http://hudoc.echr.coe.int/ (accessed 12 May 2005).

9 For a full list of signatories see http://www.iwraw-ap.org/protocol/list_signatories.htm (accessed 12th May 2005).

10 For example see the Covenant on Civil and Political Rights.

11 In a joint statement between the Special Adviser on Gender Issues and Advancement of Women, Ms Angela E.V. King, and the High Commissioner for Human Rights, Mrs Mary Robinson, on the occasion of the opening for signature of the Optional Protocol to the Convention on the Elimination of All Forms of Discrimination against Women. Available in full at www.un.org/womenwatch/daw/news/akop.htm (accessed 12 May 2005).

12 International Federation of University Women - http://www.ifuw.org/advocacy/ia_cedaw.htm\# monitor (accessed 12 May 2005).

13 UNIFEM, Areas of Work. For full details see http://www.unifem.org/index.php?f_page_pid=45 (accessed 12 May 2005).

14 For full details see http://www.iwraw-ap.org/aboutus/history.htm (accessed 12 May 2005).

15 This organisation runs the only refuge for women in Ulaanbaatar.

\section{References}

Afsharipour, A. (1999), 'Empowering ourselves: the role of women's NGOs in the enforcement of the women's convention', Columbia Law Review, 99, 1, 129-172.

Ali, S.S. and Rehman, J. (2003), 'Freedom of religion vs equality in international human rights law: conflicting norms or hierarchical human rights? (A case study of Pakistan)', Nordic Journal for Human Rights, Vol 21 404-428.

Amnesty International (2001), Human Rights for All, London: Amnesty International.

Benedek, W. Kisaakye, E.M. and Aberleitner, G. (2002), Human Rights of Women: International Instruments and African Experiences, London: Zed Books. 
Bigge, D.M. and von Briesen, A. (2000), 'Conflict in the Zimbabwean Courts: women's rights and indigenous self-determination in Magaya v. Magay', Harvard Human Rights Journal, 13, 289-314.

Bunch, C. (1995), 'The global campaign for women's human rights: where next after Vienna', St. John's Law Review, 69, 1-2, 171-178.

Charlesworth, H. (1994), 'What are "Women's International Human Rights"?', in R.J. Cook, Human Rights of Women: National and International Perspectives, Philadelphia: University of Pennsylvania Press, pp. 58-84.

Coomaraswamy, R. (1994), 'To bellow like a cow: women, ethnicity and the discourse of rights', in R.J. Cook, Human Rights of Women: National and International Perspectives, Philadelphia: University of Pennsylvania Press, pp. 39-57.

Dairiam, S. (2003), 'Report Round Table discussion: rights and obligations under CEDAW' (accessed on 12May 2005) http://www.suhakam.org.my/docs/document_resource/Report_RTD_CEDAW.pdf

Ilumoka, A.O. (1994), 'African women's economic, social, and cultural rights', in R.J. Cook, Human Rights of Women: National and International Perspectives, Philadelphia: University of Pennsylvania Press, pp. 307-325.

Knop, K. (1993), 'Re/statements: feminism and state sovereignty in international law', Transnational Law and Contemporary Problems, 3, 293-344.

Lawyers Center for Legal Reform Support (2002), 'First National Human Rights NGOs Forum', Papers 2-3, May 2003.

Mayer, A.E. (1998), 'Islamic reservations to human rights conventions: a critical assessment', Recht van de Islam: Human Rights and Islam, pp. 26-45.

Nash, K. (2002), 'Human rights for women: an argument for "deconstructive equality"', Economy and Society, 31, 3, 414-433.

Phillips, A. (1992), 'Universal pretensions in political thought', in M. Barratt and A. Phillips (eds), Destabilizing Theory: Contemporary Feminist Debates, Cambridge: Polity.

Stewart, A. (2004), Aspirations to Action: 25 Years of the Women's Convention (CEDAW), London: British Council.

Tang, K.-L. and Cheung, J.T.-Y. (2000), 'Guaranteeing women's rights: the UN Women's Convention', International Social Work, 43, 7-20.

UNIFEM Trust Fund (2002), 'Violence against women and legal framework in Mongolia', Ulaanbaatar: CEDAW Watch.

Weiss, A.M. (2003), 'Interpreting Islam and women's rights: implementing CEDAW in Pakistan', International Sociology, ? 18, 3, 581-601.

Weissbrodt, D. (1977), 'The role of international nongovernmental organisations in the implementation of human rights', Texas International Law Journal, 12, 293-320.

Women's Resource Centre (2002), 'Response to the Women's National Commission on the Government's Draft 5th CEDAW Report to the United Nations', Women's Resource Centre, London.

Young, I.M. (1990), Justice and the Politics of Difference, Princeton, NJ: Princeton University Press. 